\title{
Effects of Chemistry-Based Puzzles on Senior Secondary School Chemistry Students' Interest in Chemical Periodicity
}

\author{
Adzape, J. N. \\ Science Department, \\ Government Girls' College, Makurdi \\ Tel: 234-703-818-0696_E-mail: adzapejanet@yahoo.co
}

Otor, E. E.

Department of Curriculum \& Teaching,

Benue State University, Makurdi

Tel: 234-806-789-0766_E-mail: otoreribaemmanuel@gmail.com

\author{
Akpoghol, T. V \\ Department of Chemistry, \\ Benue State University, Makurdi \\ Tel: 234-803-617-7521Ｅ-mail: timversh@yahoo.com
}

Received: August 5, 2020 Accepted: October 10, 2020 Published: October 15, 2020

doi:10.5296/elr.v6i2.17836 URL: https://doi.org/10.5296/elr.v6i2.17836

\begin{abstract}
The study investigated the effects of chemistry-based puzzles on senior secondary school chemistry students' interest and gender in chemical periodicity. The design of the study was quasi-experimental; specifically the pre-test, post-test non-equivalent control group design was adopted. A sample of 129 students from a population of 4369 was used in the study. Students were classified into experimental and control groups: Students in the experimental groups were instructed with chemistry-based puzzles while students in the control groups
\end{abstract}


were instructed with the demonstration method. An interest questionnaire called Chemical Periodicity Concepts Interest Inventories (CPCII), constructed by the researchers and validated by experts from three universities in Nigeria, was used in the study. Reliability coefficient of the instrument was calculated and found to be 0.79 . Three research questions and three hypotheses were raised in the study. The research questions were answered using Mean and Standard Deviation while hypotheses were tested at 0.05 confidence level using Analysis of Covariance (ANCOVA). Findings showed that students in the experimental group who were taught with Puzzle-Based Strategy (PBS) had higher interest in the topic 'chemical periodicity' than those in the control group who were taught with the Demonstration Method (DEM). There was no significant difference in the interest of students by gender. Interaction effect of gender and treatments on interest was not significant. It was recommended that teachers should incorporate puzzle-based instructional strategies in their teaching as a variety to curb boredom in the classroom due to monotony of the conventional methods among others.

Keywords: Interest, Chemical periodicity, Chemistry-based puzzles, Gender, Interaction effect

\section{Introduction}

Chemistry is one of the three main branches of pure science; the other two are biology and physics. Chemistry deals with the composition, properties and uses of matter (Ababio, 2011). However, chemistry proves a difficult subject for many students (Sirhan, 2007). Chemistry is a human endeavor that relies on basic human qualities like creativity, insights, reasoning, and skills (Banya, 2005).

Ezeliora (2009) rated chemistry as the most important of all the sciences due to its central position to man's survival. Chemistry is commonly viewed as the "central science", as mastery of its concepts regarding the structure of matter is essential to further course work in all sciences. In essence, chemistry performs the function of gatekeeper for future study in many sciences.

The use of teaching aids induces active participation in learning and helps students to learn with interest and understanding. Bassey, Asim and Essien (2005), Akpan (2008) and Arokoya and Ugonwa (2012) have observed that teaching aids would inevitably better the performance of students, thus helping to prepare them for useful and purposeful living within the wider environment. They however concluded that for Nigeria to develop in the area of science and technology, the teaching of chemistry must be supported by adequate provision of material resources, required for effective instructions. Udo (2006) noted that the effective and meaningful teaching of abstract scientific concepts require active students' involvement in the teaching-learning process through meaningful and relevant hands-on activities. Guidelines from the Federal Ministry of Education for the inspection of chemistry in the senior secondary schools and technical colleges recommend activity oriented and participatory methods for effective teaching and learning of chemistry in secondary schools (FME, 2002). On the other hand Oyeshola (2010) noted that even in a rich economy it is not possible for government to equip the schools with all they need, the option is for teachers to make the best of what they can get or construct. However, many teachers are not ready to use innovative ways of teaching chemistry concepts to students but rely on the traditional method of "chalk 
and talk' which has worsened matters (Ezennagha, 2008; Udo \& Eshiet, 2007).

An important concept in learning which is considered in this study is interest of the learner. Imoko and Agwagah (2006) have looked at interest as a subjective feeling of concentration or persisting tendency to pay attention and enjoy some activity or content. According to Imoko and Agwagah, children's interest needs to be stimulated in order to learn, even though they are physically and intellectually capable of learning. Once stimulated, they continue to learn as long as the teacher is capable of sustaining their interest in the subject matter. It is the responsibility of the teacher to create an interesting environment for learning in order to catch the attention of the learner. Such an environment can be created by the use of puzzles in teaching and learning. A study by Franklin, Peat and Levis (2003) indicated that learning with puzzles can increase motivation and students' interest in the topic at hand. These researchers and Moore and Dettlaf (2005) observed that puzzles have been shown to be effective teaching tools of terminology, definitions, spellings and pairing key concepts with related names, resulting in greater retention and memorization of facts as well as interest in the topic being learnt.

Materials presented in a more powerful context have been found to empower students and enhance situational interest (Chen, Darst, \& Pangrazi, 2001). This is because interest is the mother of attention, once there is direct interest, attention is guaranteed and learning is assured. Also interest can be expressed through simple statements made by individuals of likes and dislikes and one is likely to do well in a discipline of interest (Okigbo \& Okeke, 2011). The result of an empirical study of 200 students over a two year period indicates that using puzzle-based learning as an interest approach can significantly change the students' experience. This includes increasing students' interest and scope for active participation in the course, and developing their critical thinking and problem-solving skills (Merrick, 2010).

Chemistry-based puzzles can be of benefit to the user as they promote the development of scientific attitudes such as objectivity, honesty, curiosity, patience, open-mindedness. Users also develop science process skills such as observing, classifying, predicting, drawing conclusion, recording data and hypothesizing (Achimugu, 2012). Achimugu also noted that chemistry-based puzzles arouse and maintain curiosity in chemistry students and discourage rote memorization.

Chemistry-based puzzles fall under the category of serious games called edutainment, which is educating through entertainment (Michael \& Chen, 2006). Games may be played seriously or casually, according to Michael and Chen and they have explicit and carefully thought out educational purpose and are not to be played primarily for amusement. Studies with games show that peoples motivation increase when they participate in game-based activity (Siang \& Rao, 2003). For this reason, the educational games (puzzles) are considered in this study. According to Dingle (2012) "the majority of kids understand most of the chemistry behind the periodic trends typically asked in free response questions, but too often they cannot express that knowledge in succinct, meaningful English that allows (and encourages) the graders to award credit". As a result students tend to score poorly on a topic that really ought to be an area that yields more points.

Applying chemistry-puzzles in solving the problem of difficulty and lack of interest in understanding the Periodic Table is the main thrust of this research. This is because a lot of 
questions from WAEC/NECO SSCE are based on the periodic table. The Periodic Table also spans the whole of general chemistry and it forms the bases for other topics in chemistry (Toon et al., 2011). Although lecturing may be the most prevalent teaching tool, it is less effective way to facilitate students' learning (Mohammed, 2011). Obiekwe (2008) reported that all is not well with science instruction in Nigerian secondary schools, and noted that science teaching lays extreme emphasis on content and the use of "Chalk and talk" method. The relevance of chemistry needs to embrace relevant teaching approaches to the teaching of the subject in schools (Holbrook, 2005). For this reason the teacher must teach with purpose for learners to achieve meaningfully.

Gender is another variable which needs to be tested in this study because concern has been shown by researchers on this issue in science. Gender is an attribute of being male or female. Gender differences have become the hot list of critical issues around the world. Studies on gender and interest in science have not been consistent. While the majority of studies found out that female students performed better than male students, others found the opposite; on the other hand, other researchers found no differences at all between males and females concerning interest and success. Gender differences according to Khwaileh and Zaza (2011) and Okebukola (2002), are widest at secondary level of education. Okoli (2012) noted that women scientist and engineers are treated as unusual in industry and most academia. Okebukola (2004) reported that in spite of the fact that $50 \%$ of the population of Nigeria is women only $11 \%$ of personnel in science, technology and engineering professions are women. The researcher concluded that the under representation of women and girls in science and technology education is traceable to gender role stereotyping that is prevalent in different countries. A declining interest in chemistry and the under representation of females in the chemical science was found, (Banya, 2005). It is for these reasons that the researchers seek to ascertain the effects of teaching withchemistry-based puzzles on interest of senior secondary chemistry students.

\subsection{Statement of the Problem}

The concept of chemical periodicity has been established as difficult to students. The periodic table itself is complex for students to memorize or learn all the elements in it, so as to meet up with their knowledge in examination questions set on them. Activity oriented classes are needed to enhance better understanding of the arrangement, trends and properties of all the elements on the periodic table. This activity based teaching is lacking in the teaching of this topic as is evident in literature that most teachers depend on the traditional method. This brings about lack of interest in this topic and subsequent failure in the subject. Evidence has also shown that interest is a necessary factor for achievement and this is lacking in the case of science students who learn by rote memorization of concepts. To crown it all, the interest of the learner is marred due to lack of activities which should ginger them to learn. Lastly, gender stereo-typing has not helped matters. To this end, the researchers adopted puzzle-based teaching strategy using chemistry-based puzzles which they hoped will stimulate interest and enhance learning of the subject.

\subsection{Purpose of the Study}

The general purpose of the study was to determine the effects of science-based puzzles on senior secondary students' interest in chemical periodicity. Specifically, the study ascertained 


\section{Macrothink}

Education and Linguistics Research

ISSN 2377-1356

2020, Vol. 6, No. 2

the

1) effect of teaching with chemistry-based puzzles on the mean interest scores of students in chemical periodicity.

2) effect of gender on the mean interest scores of students in chemical periodicity.

3) interaction effect of gender and treatments on students' mean interest scores in chemical periodicity.

\section{Theoretical Background}

This study was anchored on Vygotsky's social constructivist theory. The emphasis is on social interaction to explain children's cognitive developments. Puzzles are an aspect of games which promote children's social interaction both in and outside the classroom. They can be applied in teaching of specific concepts and can aid students to learn faster, hence the relevance of this theory to the study.

\subsection{Research Questions}

The following research questions were answered in the study:

1) What is the difference in the mean interest scores of students taught chemical periodicity with chemistry based puzzles and those taught with the demonstration method?

2) What is the difference in the mean interest scores of male and female students taught chemical periodicity using chemistry-based puzzles?

3) What is the interaction effect of gender and treatments on students' mean interest scores in chemical periodicity?

\subsection{Hypotheses}

The following null hypotheses were formulated and tested at 0.05 level of significance.

1) There is no significant difference in the mean interest scores of students in chemical periodicity who are taught with chemistry-based puzzles and those taught with the demonstration method.

2) The mean interest scores of male students do not significantly differ from their female counterparts when taught chemical periodicity using chemistry-based puzzles and those taught with the demonstration.

3) There is no significant interaction effect of gender and treatments on students' mean interest scores in chemical periodicity.

\section{Research Methodology}

The study used the quasi-experimental design. Specifically, the non-randomized control group, pretest-posttest design was adopted in the study. The design is represented as follows:

\begin{tabular}{llcl}
\hline Group & Pretest & Independent Variable & Posttest \\
\hline E & $\mathrm{O}_{1}$ & $\mathrm{X}_{1}$ & $\mathrm{O}_{2}$ \\
$\mathrm{C}$ & $\mathrm{O}_{1}$ & $\mathrm{X}_{2}$ & $\mathrm{O}_{2}$ \\
\hline
\end{tabular}


Where $\mathrm{E}=$ Experimental group

$\mathrm{C}=$ Control group

$\mathrm{O}_{1}=$ Pretest for the two groups

$\mathrm{O}_{2}=$ Posttest for the two groups

$\mathrm{X}_{1}=$ Treatment for the Experimental group

$\mathrm{X}_{2}=$ Treatment for the Control group.

The study was carried out in Makurdi Local Government Area of Benue State, Nigeria. The population of the study was 4,369 Senior Secondary Two (SS2) science students in Makurdi Local Government Area of Benue State. This comprised 2,439 male and 1,930 female science students spread in the 76 senior science schools located in Makurdi Local Government area of the state as at the time of the research (MOE, 2013). The SS2 students were suitable for the study because the topic - chemical periodicity-is treated at this level as part of the chemistry curriculum content.

A sample of 129 students was obtained through multistage sampling procedure. All senior secondary schools located in Makurdi metropolis were proportionally stratified into North bank and South bank schools. Purposive sampling technique was carried out to select four schools; two each from the North and South banks. The schools were co-educational in order to remove sex bias since gender was also one of the variables to be tested in the study. The four schools were randomly assigned to experimental and control groups. Two schools were assigned to the experimental groups and two to the control groups.

Chemical Periodicity Concepts Interest Inventory (CPCII) was the instrument used for the study. This instrument was developed by the researchers and validated by experts from University of Nigeria, Nsukka; Benue State University, Makurdi and University Agriculture, Makurdi. The inventory was made up of two sections. Section A, sought information on the bio-data of students and Section B contained 30 statements covering students' interest in chemical periodicity.

A trial test was conducted to test the appropriateness of the instrument on 30 SS2 chemistry students and the data obtainedwas analyzed using Spearman Brown formula for CPCII.The test/re-test and internal consistency reliability for interest inventory was calculated and found to be 0.79 for CPCII.Four chemistry teachers were recruited and trained as research assistants. Treatment in the two groups lasted for six weeks after which a post test was given.

The research questions were answered using descriptive statistical tools; means and standard deviations. Analysis of covariance (ANCOVA) was used to test all the hypotheses at a 0.05 level of significance.

\section{Results}

\subsection{Research Question 1:}

What is the difference in the mean interest scores of students taught chemical periodicity with chemistry-based puzzles and those taught with the demonstration method? 
Table 1. Mean $(\bar{X})$ and Standard Deviation (SD) of interest scores of students taught chemical periodicity

\begin{tabular}{lllllll}
\hline Group & Pre-test & \multicolumn{5}{c}{ Post-test } \\
\hline & $\mathrm{N}$ & Mean & SD & Mean & S.D. & Mean Gain \\
PBS & 65 & 78.81 & 10.98 & 95.22 & 9.10 & 16.41 \\
DEM & 64 & 65.16 & 13.84 & 72.13 & 9.47 & 6.97 \\
\hline
\end{tabular}

Table 1 shows that the interest scores of students who were exposed to chemistry-based puzzles as an instructional strategy had a mean interest score of 95.22 with a standard deviation of 9.10 at posttest while those taught with demonstration method had a post-test mean interest score of 72.13 with a standard deviation of 9.47. The difference in mean gain of 9.44 shows that the students taught with PBS had a higher mean interest score than those taught with DEM.

Hypothesis 1:

There is no significant difference in the mean interest scores of students in chemical periodicity between those taught with chemistry-based puzzles and those taught with the demonstration method.

Table 2. Analysis of covariance of the effect of treatments on students' interest in chemical periodicity

\begin{tabular}{llllll}
\hline Sources & Sum of Squares & DF & Mean square & F & Sig Level \\
\hline Pretest & 0.065 & 1 & 0.065 & 0.001 & .978 \\
Main effect & 17100.318 & 2 & 8550.159 & 97.293 & .000 \\
Group & 17100.318 & 1 & 17072.03 & 194.264 & .000 \\
Gender (Sex) & 3.258 & 1 & 94.425 & 0.037 & .848 \\
Gender*Group & 53.630 & 1 & 53.630 & 0.610 & .436 \\
Explained & 17250.381 & 4 & 547.308 & 49.073 & .000 \\
Residual & 10897.170 & 124 & 28.353 & & \\
Total & 28147.550 & 128 & 219.903 & & \\
\hline
\end{tabular}

Table 2 shows that the calculated value for the effect of treatment on students' interest in chemical periodicity has a probability value of 0.00 which is less than 0.05 level of significance $(\mathrm{P}<0.05)$. Thus, there is a significant difference in the mean interest scores of students taught chemical periodicity; hence the null hypothesis is rejected.

4.2 Research Question 2:

What is the difference in the mean interest scores of male and female students taught 
chemical periodicity?

Table 3. Mean and standard deviation of interest scores of male and female students in chemical periodicity in the experimental group

\begin{tabular}{lllllll}
\hline Gender & Pre-test & \multicolumn{5}{c}{ Post-test } \\
& $\mathrm{N}$ & Mean & SD & Mean & SD & Mean Gain \\
\hline Male & 74 & 71.61 & 14.08 & 84.16 & 14.91 & 12.55 \\
Female & 55 & 72.35 & 14.50 & 83.21 & 14.83 & 10.86 \\
\hline
\end{tabular}

Table 3 revealed that the male students had a mean interest score of 84.16 with a standard deviation of 14.91 at post-test while their female counterparts had an interest mean score of 83.21 with a standard deviation of 14.83 . The figures reveal that the male students had a slightly higher mean gain (1.69) on interest score than their female counterparts.

Hypothesis 2:

The mean interest scores of male students do not significantly differ from their female counterparts who are taught chemical periodicity with chemistry-based puzzles and the demonstration method.

With reference to table 2, it is observed that the calculated value $\mathrm{P}$ for influence of gender on students' interest in chemical periodicity is 0.85 . Thus gender has no significant influence on students' interest in chemical periodicity since the probability value of 0.85 is greater than the probability at 0.05 level of significance $(\mathrm{P}>.05)$

\subsection{Research Question 3:}

What is the interaction effect of gender and treatments on students' mean interest scores in chemical periodicity.

Table 4. Mean and standard deviation of interest scores of students for the interaction effects of gender and treatments in chemical periodicity

\begin{tabular}{crrrr}
\hline Group & \multicolumn{2}{c}{ Gender } \\
\hline & \multicolumn{2}{c}{ Male } & \multicolumn{2}{c}{ Female } \\
\hline \multirow{2}{*}{ PBS } & Mean & N & Mean \\
DEM & 39 & 94.56 & 26 & 96.19 \\
\hline
\end{tabular}

Result in Table 4 shows that male students in PBS had a post test mean interest score of 94.56 while their male counterparts in DEM had a mean interest score of 72.57. On the other hand, the female students in PBS had a mean interest score of 96.19 while their female counterparts in DEM had a mean interest score of 71.59. 


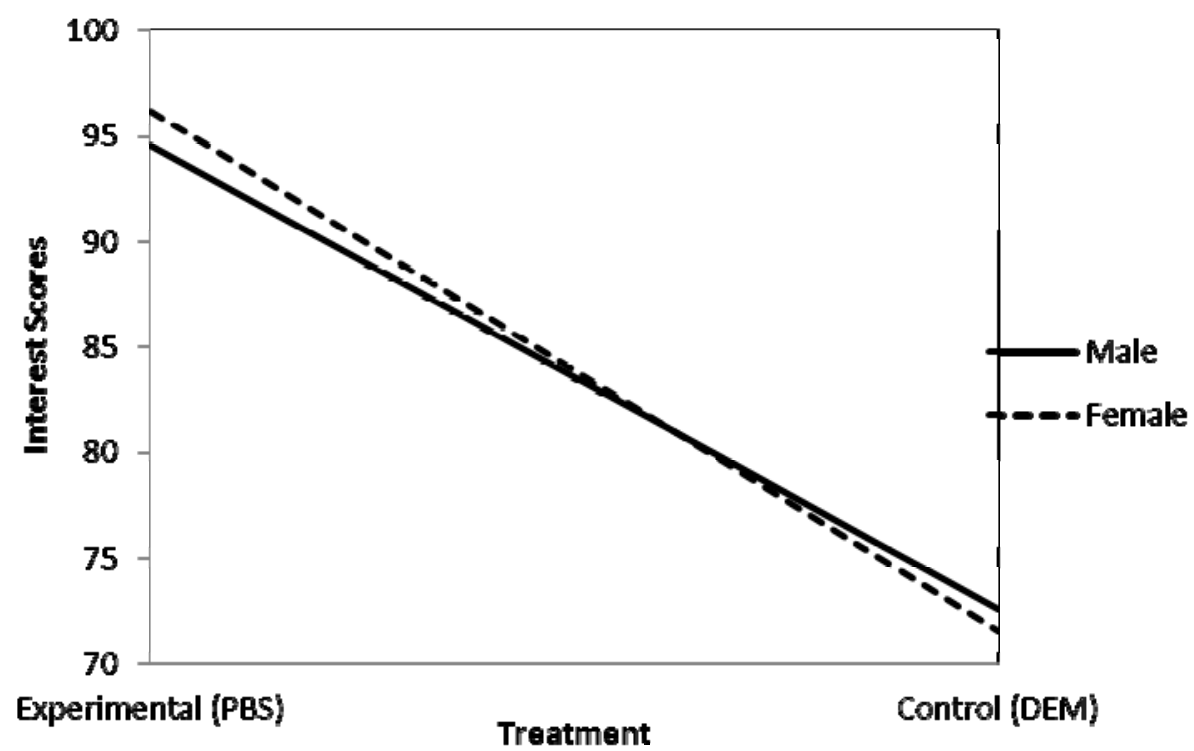

Figure 1. A plot of interaction by gender and treatments on interest scores of students The plot shows a disordinal type of interaction.

\section{Hypothesis 3}

There is no significant interaction effect of gender and treatments on students' mean interest scores in chemical periodicity.

Data analysis in Table 2 showed that the calculated value of $p$ for the interaction effect of gender and treatments on students' interest in chemical periodicity is 0.44 . Thus there is no significant interaction effect in the mean interest scores of students taught chemical periodicity with chemistry-based puzzles and those taught with the demonstration method. This is for the fact that the probability value of 0.44 is greater than the probability at 0.05 level of significance $(\mathrm{P}>$.05). The null hypothesis is therefore not rejected.

\subsection{Discussion of Findings}

The findings in the study were discussed under the following headings:

1) Effect of treatment on students' interest in chemical periodicity.

2) Effect of gender on students' interest in chemical periodicity.

3) Interaction effect of gender and treatments on students' interest in chemical periodicity.

The result in Table 1 used in answering research question 1 revealed that students in PBS group had a higher mean interest score than those in DEM group. This is because the students in the PBS group were subjected to chemistry-based puzzles in learning the topic 'chemical periodicity'. This finding is in line with earlier studies of Merrick (2010) and Vansteenkist et al. (2004) who agree that individual students' interest has positive effect on learning and academic achievement.

Further analysis using ANCOVA at 0.05 significance level proved that interest is a significant factor in learning chemical periodicity with chemistry-based puzzles. Students' interest in the topic when taught with puzzles was overwhelming. This also reflected in the high mean interest score by that group over the control group. 
Interest of students is a necessary factor which can sustain them in a lesson. PBS facilitated students' interest in the topic than the conventional Demonstration Method because it is activity based and learner centered. Just as Ryan and Deci (2000) recognized the importance of individual interest and its role in individual learning and achievement, Okigbo and Okeke (2011) confirmed that students do well in discipline of interest; Chen, Darst and Pangrazi (2001) advised teachers to seek the interest of students when delivering a lesson. This can be done when puzzle based teaching strategy is adopted just as the finding have proven. Moreover, research has shown that individual interest has a direct effect on achievement. Interest is like bait which brings achievement to the hook

The overall mean interest score of students taught chemical periodicity using chemistry-based puzzles is shown in table 3 . The result indicated that male students achieved higher than female students at post test. Analysis of covariance revealed that this difference was not significant. This shows that gender is not a factor in students' interest in chemical periodicity. This implies that both parties share same interest in the topic when taught with puzzles. This finding is consistent with that of Lipstein and Renninger (2006) and Dingle (2012) who found that individual interest was not dependent on gender.

Physical observation in the classroom showed that interest of students was captured more in the PBS group than in the DEM group but the male and female students were equally interested in learning with puzzles. Studies have persistently reported gender differences in achievement and interest of students in chemistry all in favor of males but this was not the case. The advice was that teachers should use gender equitable instructional strategies in science classroom environment and fortunately, PBS is one of such.

Result in Table 4 indicates that although students' mean interest scores in PBS group were higher than those in DEM, further analysis proved not significant. This showed that there is no significant interaction effect of treatments and gender on students' interest in chemical periodicity.

The slopes in figure 1show that females in the PBS classroom had higher interest scores than their male counterparts. On the other that hand, males In the PBS group had higher interest score than males in the DEM group. This shows that female students in the PBS group were more interested in the topic as a result of the teaching strategy. As a matter of fact most of them encountered these puzzles for the first time especially the scrabble game. This discovery is necessary and crucial in closing up the gender gap which already exists in most research findings. This finding is in line with the findings of Okebukola (2004) and Okoli (2012) which show that gender gap exists in the choice of science related courses as a result of lack of interest in science by female students. To break this barrier, puzzles could be applied in the classroom teaching to close this gap.

\section{Conclusion}

Based on the findings of this study, the following conclusions were drawn;

1) Puzzle-based teaching strategy was found to be more effective than the demonstration method on students' interest in chemical periodicity.

2) There was no significant difference in the interest of male and female students taught with Puzzle-Based Strategy. 


\section{Macrothink}

3) There was no significant interaction effect of treatments and gender on students' mean, interest scores.

\subsection{Educational Implications of the Findings}

1). The result of the study has some educational implications for teachers, students, curriculum planners, text authors and the larger society.

2). The findings of the study has provided empirical evidence in respect of the efficacy of chemistry-based puzzles as teaching models in facilitating students' interest in senior secondary chemistry. This suggests the need for teachers to lay less emphasis on the conventional methods of teaching which are teacher centered and emphasize the student centered methods.

3). The findings of the study offer students an opportunity to learn in a more relaxed environment and interact with their classmates in a social environment. This will make them to appreciate chemistry and other science subjects better.

\subsection{Recommendations}

Based on the findings, the following recommendations were made:

1) Chemistry-based puzzles should be introduced in secondary schools at the senior school level to teach chemistry concepts explicitly to students.

2) Teachers should be resourceful, and should not wait for their employers to do everything for them.

3) Schools should organize competitions centered on science-based puzzles so as to expose their students to these puzzles and all its benefits.

4) Authors and publishers of educational resources should tap into the findings of this study to write texts which should incorporate puzzles as part of the main text or as a section for questions.

5) Puzzles are available on the internet and can be created by individuals, groups; parents and guardians are advised to encourage their wards to use them to occupy their idle hours.

\section{References}

Ababio, O. Y. (2011). New school chemistry for senior secondary schools. In L. E. S. Akpannisi, \& H. Igwe (Eds.), (6th ed.), Onitsha: Africana First Publishers Plc.

Achimugu, L. (2012). Strategies for effective conduct of practical chemistry works in senior secondary schools in Nigeria. Journal of Science Teachers Association of Nigeria. Retrieved from stanonline.org/journalpdf

Akpan, O. U. (2008). Analysis of classroom interaction of senior secondary chemistry teachers in Ikot Ekpene Local Government Area of Akwa Ibom State, Nigeria. Journal of Science Teachers Association of Nigeria, 43 (1 \& 2), 16-22.

Arokoya, A., \& Ugonwa, R. C. (2012). Assessment of resource availability for chemistry instruction in the secondary schools in Rivers State. Journal of Emerging Trends in Educational Research and Policy Studies (JETERAPS), 3(3), 346-351.

Banya, J. (2005). The effects of Brain-based learning on academic achievement and retention of knowledge of science course. Electronic Journal of Science Education, 12(1).

Bassey, U. U., Asim, A. E., \& Essien, M. I. (2005). A Trend analysis of African senior 
secondary certificate examination results in science, technology and mathematics (STM). Implications for instructions in Nigerian secondary schools. Proceedings of 31st Annual Conference of International Association for Educational Assessment Abuja.

Chen, A., Darst, P. W., \& Pangrazi, R. P. (2001). An examination of situational interest and its sources. British Journal of Educational Psychology, 71, 383-400. https://doi.org/10.1348/000709901158578

Deci, E. L. (2001). The relation of interest to the motivation of behavior; A self-determination theory perspective. In K. A. Renninger, S. Hidi, \& A. Krapp (Eds.), The role of interest in Learning and development. Hillsdale: Lawrence Erbaum Associates.

Dingle, H. (2012). wikipedia.org/wiki/Cyril-Burt.

Emaikwu, S. O. (2011). Fundamentals of Research Methods and Statistics. Makurdi: Selfers Academic press Limited.

Ezeliora, B. (2009). Nurturing young chemists. In Olayiwola \& Umoh (Eds.), Science Teachers Association of Nigeria: Chemistry Panel Workshop Proceedings, Kano: Abioye Dynamic Printers.

Ezennagha, G. N. (2008). Chemistry teachers' competence on the use of concept mapping: A tool for teaching difficult concepts in chemistry. In U. Nsikak-Abasi (Ed.), Curriculum development in Science Technology and Mathematics (STM) education (pp. 144-147). STAN proceedings of the 49th Annual Conference. HEBN Publishers Plc.

Federal Ministry of Education. (2002). Guidelines for the inspection of chemistry in senior secondary schools and technical colleges, Abuja; Ages Communications Ltd.

Franklin, S., Peat, M., \& Levis, A. (2003). Non-traditional intervention to stimulate discussion: The use of games and puzzles. Journal of Biological Education, 37(2), 76-82. https://doi.org/10.1080/00219266.2003.9655856

Holbrook, J. (2005). Making chemistry teaching relevant.Chemical Education International, $6(1)$. A paper based on the lecture presented at the $18^{\text {th }}$ ICCE Istanbul, Turkey, 3-8.

Imoko, I. B., \& Agwagah, U. N. (2006). Improving students' interest in mathematics through the concept mapping technique: A focus on gender. Journal of Research in Curriculum and Teaching, 1(1), 30-38.

Khwaileh, F. M., \& Zaza, H. I. (2011). Gender differences in academic performance among university graduates at the University of Jordan: Are they real or stereo-typing? College Students Journal, 45(3) 254-262.

Lipstein, R., \& Renninger, K. A. (2006). 'Putting things into words' 12-15 yearsold students' interest for writing.In P. Boscolo, \& S. Hidi (Eds.), Motivation and writing; Research and school practice. New York; Kluwer Academic/plenum.

Merrick, K. E. (2010). An Empirical Evaluation of Puzzle - Based Learning as an Interest Approach for Teaching Introductory Computer Science. IEE Transactions on Education. https://doi.org/10.1109/TE.2009.2039217

Michael, D., \& Chen, S. (2006). Serious games.Boston: Thomson Course Technology PTR.

Mohammed, A. U., Bello, M., \& Gwandu, A.D. (2010).Teachingchemistry in a global economic crisis. In U. N. Abasi, (Ed.), STAN Proceeding of the 51st Annual Conference, (pp. 
293-297) HEBN Publishers.

Moore, L. S., \& Detlaff, A. J. (2005). Using Educational games as a form of teaching in social work, 29(1), 58-72.

Obiekwe, C. L. (2008). Effects of constructivist instructional approach on students' achievement and interest in basic ecological concepts in biology. Unpublished MSc. Ed Thesis, University of Nigeria Nsukka.

Okebukola, P. A. (2004). Gender equity in science classrooms. A paper presented at UNESCO conference, Pretoria, U.S.A.

Okigbo, E. C., \& Okeke, S. O. C. (2011). Effects of games and analogies on students' interest in mathematics.Journal of Science Teachers Association Nigeria, 46(1), 101-112.

Okoli, J. N. (2012a). Gender Mainstreaming: A strategy for promoting gender equality in science and technology education. Journal of Science Teacher Association of Nigeria, 47(1), 96-104.

Oyesola, O. (2010). Global economic meltdown and its implication for Nigeria. In O. Nsikak-Abasi (Ed.), Developing entrepreneurial skills through Science Technology and Mathematics Education. 50th Annual Conference of Science Teachers Association of Nigeria.

Ryan, R. M., \& Deci D. L. (2000). Intrinsic and extrinsic motivations: Classic definitions and new directions. Contemporary Educational Psychology, 25, 54-67. https://doi.org/10.1006/ceps.1999.1020

Siang, C. A., \& Rao, K. R. (2003). Theories of learning; A computer game perspective. Proceedings of the IEE, Fifth International Symposium on Multimedia Software Engineering, (ISMSE). https://doi.org/10.1109/MMSE.2003.1254447

Sirhan, G. (2007). Learning difficulties in chemistry: An overview. Journal of Turkish Science Education, 4(2), 2-20.

Toon, T. Y., Kwong, C. L., Sadler, J., Tsoi, R., Edema, M. O., \& Umobi, C. I. (2011). New system chemistry for senior secondary schools. Africana First Publisher Plc. Onitsha, Nigeria. Udo, M. E. (2006). The Chemistry of corrosion of metals: A resource for effective teaching of Redox reaction and electrochemistry. Journal of Science Teachers Association of Nigeria, 4(1\&2), 44-50.

Vansteenkiste, M., Simons, J., Lens, W., Sheldon, K. M., \& Deci, E. L. (2004). Motivating, learning, performance and persistence: The synergistic effects of intrinsic goal contents and autonomy-supportive contexts. Journal of Personality and Social Psychology, 87, 246-260. https://doi.org/10.1037/0022-3514.87.2.246

\section{Copyright Disclaimer}

Copyright reserved by the author(s).

This article is an open-access article distributed under the terms and conditions of the Creative Commons Attribution license (http://creativecommons.org/licenses/by/3.0/). 